\title{
Sufi and Philosophical Heritage of Jalaluddin Rumi
}

\author{
Karomat Kilicheva \\ Journalism and Mass Communication University of Uzbekistan, Tashkent, Uzbekistan \\ Corresponding author email: karomatkilicheva320@gmail.com
}

Gavkhar Klicheva

School of Psychology, Korea University, Seoul, South Korea

Email: klichevagavkhar@gmail.com

\begin{abstract}
Rumi was one of the most famous Sufi, poet, and spiritual teachers who have globally drawn the attention of many. Rumi's teachings have been valued and used by Sufi masters after him, and are studied in contemporary mystic circles. Not only Sufis, but others as well refer to his teachings for lessons, and those who enjoy poetry are intoxicated by Rumi's magical words. He views that, humans tend to move upwards to realize their potential. Rumi's poetry whether or not is the result of his ecstatic moment is a reflection of his close relationship with people around him. Despite his greatness as a scholar, he always mingled with society, listened to their sharing, and advised them to solve the problem. This interaction created a paradigm that enabled him to see things as a whole, in an interactional way that is interconnected as a harmony. Thus, this paper attempts to review and analyze Rumi's life and his contributions in the fields of spirituality and philosophy.

Keywords---Masnavi, philosophy, Rumi, sufi poetry, sufism
\end{abstract}

\section{Introduction}

Jalaluddin Rumi was born and raised in Balkh. Hence, sometimes he is called Jalaluddin Balkhi. Known as Rumi or Mevlana, he is a well-known Persian-Tajik Sufi poet who wrote mainly Oriental poetry in Persian. Rumi created masterpieces in all forms of poetry. His poems, rubais, and masnavis, which are mystical and extensive poems written in Persian (Vafaeifard \& Kazazi, 2017), have become masterpieces of poetry. Rumi's works are full of philosophical, Sufi, and profound ideas wrapped in metaphors. Jalaluddin was well educated not only in the field of religion and law, but also in sciences, and was fluent in Arabic, Greek, the Qur'an, and its interpretation. In the 13th century, in the city of Kunya, after Sultan Valad founded the Sufi order of Mevlana, and Rumi's works were used in ceremonies. Rumi is the spiritual successor of the most influential dervishes in Ottoman Turkey and the existing sect of our time. Sheikh Shams Tabrizi and Farid al-Din Attar, the enlighteners of that time, made an invaluable contribution to the development of Rumi in the field of poetry, philosophy, and theology. From Shams Tabriz, he became acquainted with philosophy, especially Sufism. Jalaluddin's conversion to Sufism is associated with the name Shamsuddin Tabrizi. For almost ten years after meeting Shamsuddin, Rumi devoted himself to writing ghazals. He made a compilation of ghazals and named it Diwan-e-Kabir or Diwan-e Shams-e Tabrizi. Thereafter, Rumi encountered a goldsmith - Salauddin Zarkub - whom he made his companion. When Salauddin Zarkub died, Rumi befriended one of his favorite disciples named Hussam Chalabi. Rumi spent most of the later years of his life in Anatolia, where he finished six volumes of his masterwork, the Masnavi (Ansari, 2018).

Rumi's popularity has gone beyond national and ethnic borders. He is considered to be one of the classical poets, by the speakers of the Persian language in Iran, Afghanistan, and Tajikistan. For many years, he had a great influence on Turkish literature. Rumi's strength lies in the fact that he has a great poetic status and is known in the Turkic world. For all sects of Islam and other religions, he put forward a single idea, in which he sang the love of the Creator, the belief in his power, the purity of intentions and deeds. He wrote, "The paths may be different, but the 
ultimate goal is to go to God." Till the end of his life, he preached equality before God (Hawas, 2016; Werbner, 2010; Mahyudi et al., 2017).

\section{Sufi heritage of Rumi}

"Sufism" is "tasawwuf," which mainly refers not to a school of thought, ideology, identity, theology, or division of Islam but to a pursuit of spiritual cultivation that one can undertake alongside other pursuits. The most universal and central part of tașawwuf practice is the daily recitation, both individually and in the community, of litanies and sacred texts, collectively known as "dhikr." Sufi litanies usually consist of phrases from the Qur' an and hadith or variations on them, as well as sacred poetry and supplications (Hill, 2021).

Like many other mystics and Sufi poets of Persian literature, Rumi's poetry speaks of a love that infuses the world. Rumi's teachings also express the tenets summarized in the Quranic verse which Shams-e Tabrizi cited as the essence of prophetic guidance: "Know that 'There is no god but He,' and ask forgiveness for your sin". In the interpretation attributed to Shams, the first part of the verse commands humanity to seek knowledge of tawhid (oneness of God), while the second instructs them to negate their existence. In Rumi's terms, tawhid is lived most fully through love, with the connection being made explicit in his verse that describes love as "that flame which, when it blazes up, burns away everything except the Everlasting Beloved."

It is suggested that, despite his greatness, Rumi was very humble. He was not reluctant to go to market and bow before everybody who saw him. He greeted them and asked their condition. He shared many things in his house with the needy and welcomed anyone who came to his house (Zinira, 2016). Throughout years of sailing to God, he was overwhelmed with love to the Beloved, when he attained unity with God, he would energize himself with the love of the Lord, he was spiritually born many times and he was always happy with his life. His happiness brought him in harmony with all humanity (Ghavami, 2016; Kaya, 2016; Bahri et al., 2018).

In relation to what Rumi taught, his doctrinal system was essentially based around his conviction that the entire path of mystical perfection is centered around Man's desire to return to his divine origin, thereby returning to the ontological unity he had once enjoyed. For Rumi, the all $\neg$ consuming problem of human existence stems from the painful existence of imperfection caused by alienation from our essential source. His metaphysics depict the beginning of creation as a unified realm, where Man's inward reality and the virtual existence of all created things were present with God in a state of harmonious unity. In order to once again experience this origi $\neg$ nal state of spiritual perfection, Rumi emphasizes its gradual and progressive nature and insists that the mystical path involves passing through limitless successive spiritual 'stations' (Gray, 2019).

\section{The Masnavi by Rumi}

Rumi's literary work is not multifaceted, but important. His lyrical "Divan" has not yet been studied in detail and consists of poems, ghazals, and quatrains - rubai. The poet promotes the idea of human dignity in it, regardless of the glory of the world. It opposes the formalism and nonsense of a fading religious tradition. These ideas are expressed uniquely in fiery language. A number of lyrical poems speak of the practical convenience, vital and philosophical fanaticism of Sufism (Mirdal, 2012; Harel et al., 2021; Carminati et al., 2006).

The combination of stability and practicality is characterized by Jalaluddin's "Masnavi" - a huge (about 50,000 verses) epic-didactic poetic work. Here, epic stories are followed by exhortations or lyrical digressions, and the same ideas only come in more popular forms. In general, the stories form an encyclopedia of Sufism. There is no plot integrity in Masnavi, but all his works are in a single mood; their shape is rhyming bytes of the same tone. In the epic, Jalaluddin appears as a stable artist, and sometimes as a naturalist (his naturalism may surprise the European reader, but it is common for the East).

In the first verses of the Masnavi, the reed flute is used as a metaphor for "Insan-1 Kâmil" (human perfection) as described within the Sufi tradition. Masnavi attempts to explain the various facets of spiritual life. The Masnavi is the longest single-authored emphatically mystical poem ever written at 26,000 couplets, making it a significant work on its own. It is also arguably the second most influential text in the Islamic world after the Qu'ran. Masnavi remains one of the purest literary glories of Persia. The original Persian text was so influential that in Ottoman times a network of institutions was devoted to its study (Kharmandar \& Karimnia, 2013; Kuhrt, 1994). Masnavi contains anecdotes and stories derived largely from the Quran and the hadith, as well as everyday tales. Interestingly, Rumi distinguished humankinds and animals by emphasizing the capacities that attribute them. It is love, anger, and lust that differentiate human and animals. A man is considered as a man only if he/she has the capacities to be a man which is love and tenderness. Unless he/she owns the human qualities, they will be considered animals. A spiritual 
person should deliver himself to break with the animal characters that enable him to be born as a new person (Sloan, 2006; Craig \& Dubois, 2010).

\section{Conclusion}

Jalaluddin Rumi considers the human will as the only means of freedom, and on this basis, he decides the categories of moral principles. He notes that man is free to control his behavior. That is, one moves away from bad behavior and strives for good behavior. From the religious-mystical shell of Jalaluddin Rumi's philosophy emerges a humanistic idea of respect for the individual, brotherhood of peoples, nations, and peoples. However, there is no hatred against oppression in the works of Jalaluddin Rumi. Nevertheless, Jalaluddin Rumi was one of the greatest thinkers of his time. The main idea of the poet's poetry is love for people (Shakibaei \& Golaiji, 2012; Tucan, 2013).

\section{References}

Ansari, Z. A. (2018). Rumi: The Sufi mystic poet of Persian language. International Journal of Applied Social Science 5(12), 2302-2306.

Bahri, S., Rusdiawan, .-., \& Nuriadi, .-. (2018). Comparison of expression of God in poems written by Amir Hamzah, Chairil Anwar and Sutardji Calzoum Bachri. International Journal of Linguistics, Literature and Culture, 4(3), 64-71. Retrieved from https://sloap.org/journals/index.php/ijllc/article/view/179

Carminati, M. N., Stabler, J., Roberts, A. M., \& Fischer, M. H. (2006). Readers' responses to sub-genre and rhyme scheme in poetry. Poetics, 34(3), 204-218. https://doi.org/10.1016/j.poetic.2006.05.001

Craig, A., \& Dubois, S. (2010). Between art and money: The social space of public readings in contemporary poetry economies and careers. Poetics, 38(5), 441-460. https://doi.org/10.1016/j.poetic.2010.07.003

Ghavami, H. (2016). " Rumi and alienated man, reflecting on the concept of alienation in Masnavi" A review of selfalienation concept in Masnavi. International Journal of Humanities and Cultural Studies (IJHCS) ISSN 23565926, 1226-1241.

Gray, B. (2019). Rumi, Sufi Spirituality and the Teacher-Disciple Relationship in Elif Shafak's The Forty Rules of Love. In Re-discovering Age (ing) (pp. 47-68), transcript-Verlag.

Harel, K., Czamanski-Cohen, J., \& Turjeman, N. (2021). The spiritual experience of Sufi whirling Dervishes: Rising above the separation and duality of this world. The Arts in Psychotherapy, 75, 101831. https://doi.org/10.1016/j.aip.2021.101831

Hawas, M. A. (2016). Poetry as spiritual interpretation of Islamic architecture \& Ancient Egyptians temples. Procedia-Social and Behavioral Sciences, 225, 364-375. https://doi.org/10.1016/j.sbspro.2016.06.034

Hill, J. (2021). Sufism between past and modernity. Handbook of Contemporary Islam and Muslim Lives, 55-80.

Kaya, Ç. (2016). Rumi from the viewpoint of spiritual psychology and counseling. Spiritual Psychology and Counseling, 1(1), 9-25.

Kharmandar, M. A., \& Karimnia, A. (2013). The fundamentals of constructing a hermeneutical model for poetry translation. Procedia-Social and Behavioral Sciences, 70, 580-591. https://doi.org/10.1016/j.sbspro.2013.01.096

Kuhrt, D. (1994). The divination of reality: The conflict between mythical and instrumental, oral and written narratives, and the future of poetry. Futures, 26(1), 57-78. https://doi.org/10.1016/0016-3287(94)90090-6

Mahyudi, J., Saryono, D., Siswanto, W., \& Pratiwi, Y. (2017). Construction of visual features of Indonesian digital poetry. International Journal of Linguistics, Literature and Culture, 3(5), 1-13. Retrieved from https://sloap.org/journals/index.php/ijllc/article/view/218

Mirdal, G. M. (2012). Mevlana Jalāl-ad-Dīn Rumi and mindfulness. Journal of Religion and Health, 51(4), 12021215.

Shakibaei, Z., \& Golaiji, Y. (2012). The Effect of Mevlana's Masnavi Manavi Narratives on the Extent of Adolescent's Philosophizing Questioning Skills. Procedia-Social and Behavioral Sciences, 46, 2882-2885. https://doi.org/10.1016/j.sbspro.2012.05.582

Sloan, P. R. (2006). Kant on the history of nature: The ambiguous heritage of the critical philosophy for natural history. Studies in History and Philosophy of Science Part C: Studies in History and Philosophy of Biological and Biomedical Sciences, 37(4), 627-648. https://doi.org/10.1016/j.shpsc.2006.09.003

Tucan, D. (2013). The Quarrel Between Poetry and Philosophy: Plato-A Sceptical View on 'Poetry'. ProcediaSocial and Behavioral Sciences, 71, 168-175. https://doi.org/10.1016/j.sbspro.2013.01.023

Vafaeifard, Z., \& Kazazi, M. J. (2017). Secularism in Masnavi of Rumi. Textual Criticism of Persian Literature, 9(3), 49-62. 
Werbner, P. (2010, July). Beyond division: Women, pilgrimage and nation building in South Asian Sufism. In Women's Studies International Forum (Vol. 33, No. 4, pp. 374-382). Pergamon. https://doi.org/10.1016/j.wsif.2010.02.011

Zinira, M. (2016). Adab for a Peaceful World: A Study of Jalaluddin Rumi's Concept of Sufism. Teosofia: Indonesian Journal of Islamic Mysticism, 5(2), 67-80. 